\title{
TRENDS ON THE ARTIFICIAL FERTILIZER MARKET AND IN FERTILIZERS USE IN HUNGARY
}

\author{
Gergố Ács \\ Institute of Commerce, Budapest Business School - University of Applied Sciences
}

\begin{abstract}
The fertilizer market in Hungary is rather concentrated, which has a strong influence on the price of the fertilizer. Our domestic fertilizer use is primarily determined by that of nitrogen. The use of phosphorus is also significant but the trends in the use of potassium do not match the total quantities applied in individual years. Consequently, it can be concluded that the majority of farmers still focus on the application of nitrogen and also apply phosphorus but either neglect or do not pay enough attention to potassium fertilization. The changes in fertilizer prices between 2006 and 2017 can be broken down into two periods. Until 2012 a very important and dynamic increase was observed as a result of which the prices of N, P and K fertilizers increased by $80-120 \%, 160 \%$ and about 120\%, respectively. This was followed by a downturn in the market and in relation to 2012 prices there were 20-30/ decreases experienced until 2017 but the rate of this lagged behind the prices in other European countries. Owing to this trend the prices of N, P and K have increased by 60\%, 100\% and 80\%, respectively, over the past ten years. The correlation between fertilizer application and the prices of fertilizers in any given year is low but there is a positive one observed between fertilizer application and the fertilizer prices in the preceding year. This means supposedly that farmers mostly buy the fertilizers they wish to apply not in the current but in the preceding year and store them until these are applied. There is a strong correlation seen between fertilizer prices and the prices of corn and wheat, which means that fertilizer traders also keep tabs on economic results and also increase fertilizer prices under the influence of higher prices. Furthermore, it can be claimed that there is no correlation between crude oil prices on the world market and domestic $N$ fertilizer prices. This is an important factor since the primary base material of $N$ fertilizers is natural gas and their production involves considerable energy costs as well. It can be seen, however, that this is not what determines our domestic fertilizer prices, which can be explained by the fact that the price calculations by the determining actors on the Hungarian fertilizer market is not based on costs but on the demand.
\end{abstract}

Keywords: Fertilizer Use, Fertilizer Prices, Fertilizer Trade

(JEL Classification: Q13)

\section{INTRODUCTION}

About half of the world's crop production, food supply, foraging fibre and fuel supply is closely related to fertilizer use. According to the forecast by WHO the world's current population of 7.3 million will have increased to over nine million by the year 2050. As a result a further increase in the demand for food and feeds can be expected. In order to increase crop production it is essential to maintain a viable and efficient fertilizer application, which in turn means that an increase in fertilizer application is to be expected globally. This is also supported by a FAO study of 2015, which says that according to FAO data the fertilizer application of the world was 185 million tons effective matter in 2015. The volumes of $\mathrm{N}, \mathrm{P}$ and $\mathrm{K}$ amounted to 112 , 42 and 31 million tons, respectively. These values increased by about $2 \%$ despite the fact that they decreased owing to tense domestic interior conditions in Easter-Europe, and Central as well as Western-Asia, and because of decreasing crop buying up prices in North-America. Thus the increase was the result of the increases in Africa, Oceania, Eastern and Southern-Asia as well as Latin-America. According to forecasts the annual growth of $1-2 \%$ is to continue and so the application will have reached 200 million tons by 2020 .

Fertilizer application in the EU has decreased to one third over the past thirty years. The lowest point was in 2010 and there has been a slight increase experienced ever since.

The total mineral fertilizer application in the EU member states in 2015 - based on the data of Fertilizers Europe - was 11, 1.1 and 2.4 million tons N, P and K fertilizers, respectively (Figure 1). 
Figure 1: Agricultural uses of N, P and K fertilizers between 2006 and 2015

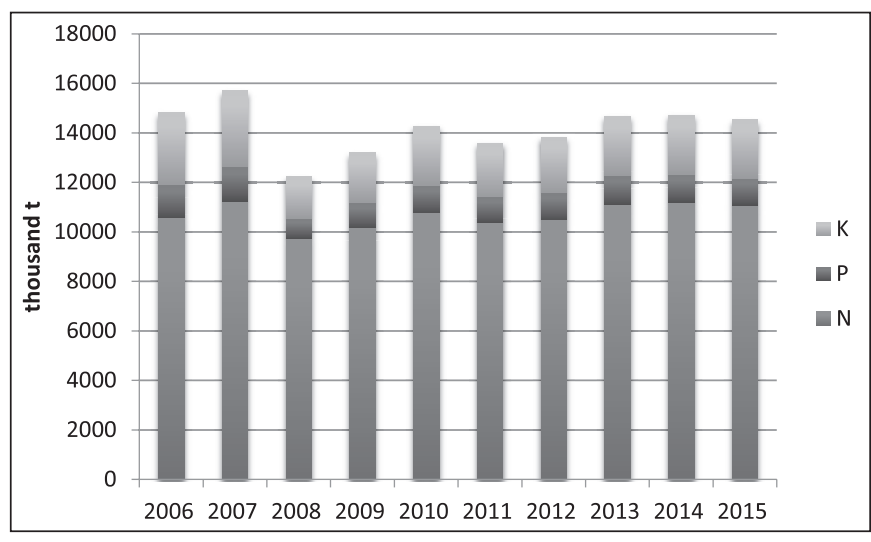

Source: private compilation on the basis of data by Fertilizers Europe 2017

The series of data well illustrates the decrease in 2008, the two reasons of which were the economic recession and the increases in fertilizer prices due to increases in fuel prices. By 2015 there was an increase again and fertilizer utilization reached the level for 2006. Current prospects and the increases in cultivated land areas indicate that further increases can be expected. These increases, however, are expected to be considerably different in individual regions of the EU. In EU-15 state and primarily in Germany considerable decreases are expected resulting from the Nitrogen regulation and as regards $\mathrm{N}, \mathrm{P}$ and $\mathrm{K}$ applications, decreases of 35\%, $50 \%$ and about $30 \%$ are calculated with, respectively. In France, Finland and the Netherlands decreases of about 10\% are expected, respectively. In the East- and Central-European region, however, considerable increases are envisaged and as a result of soars in Potassium application increases of up to 50\% are expected in Bulgaria, the Czech Republic and Romania. In Hungary increases of 20\%, 15\% and 10\% are expected in N, $\mathrm{P}$ and $\mathrm{K}$ applications, respectively. Considering all the above together a decrease of 5\% in $\mathrm{N}$ application and increases of $0.7 \%$ and $1.8 \%$ increases in $\mathrm{P}$ and $\mathrm{K}$, respectively, are forecast by 2026 (Fertilizers Europe, 2017).

Fertilizer application in Hungary shows an increasing trend although its average volume lags behind either the world or the EU average.

\section{MATERIALS AND METHODOLOGY}

In preparing the current study my general objective was the analyze of fertilizer application in Hungary over the past ten-year period and finding as well as investigating individual factors that influence the application. My special, general objective-related goals serve the purpose of providing scientifically based answers to the questions emerging in relation to the investigation.

My questions relating to the topic are the trend(s) can be observed in fertilizer application and prices in Hungary over the past decade. The prices of natural gas and crude oil's influence domestic fertilizer prices. I looked for answers the influence the given price if use of fertilizers. And the correlation between the NPK use and some potential effect factor such as yields, weather anomalies. Then I examined how can the domestic fertilizer application and prices be characterized with the help of different indicators?

In order to answer the questions I started by analyzing the available domestic and international databases and searched the illustrative world, EU and Hungarian fertilizer utilization and trade figures in secondary data collection. Next, an analysis with SPSS software of the database, which included 10 years' (2006-2015) data on the fertilizer market and agricultural crop production, compiled followed. The data lead to the calculation of partial efficiency indicators, with the help of which conclusions can be drawn on the domestic condition. In the analyses többlet space of the trends I used Excel software. Following the individual analyses correlation analyses between the domestic fertilizer utilization and other factors were carried out, such as:

- fertilizer prices in the given year

- fertilizer prices in the previous year

- corn and wheat prices in the previous year

- corn and wheat yields in the previous year

- corn and wheat average yields in the given year

- shaping of whether conditions in the given year

- crude oil prices on the world market

- natural gas prices on the world market

My research hypotheses were as follows:

1. Fertilizer prices show a continuous increase in Hungary also in the case of $\mathrm{N}, \mathrm{P}$ and $\mathrm{K}$ fertilizers.

2. Increases in fertilizer prices considerably influence the volumes applied, the more expensive the given fertilizer is, the less of it will farmers apply.

3. Fertilizer application has a considerable bearing on the management results of the previous year, i.e., in case produce selling prices are higher, higher volumes of fertilizers will be applied in the next year.

4. Owing to the concentrated fertilizer market the price calculation is not cost-based, i.e., changes in the determinant crude oil and natural gas prices are not observed by the domestic fertilizer producers.

\section{RESULTS AND DISCUSSION}

\section{Artificial fertilizer production in Hungary}

Fertilizer production in Hungary is rather concentrated and a total of twelve producers cover $80 \%$ of the whole market (Varga, 2012). The domestic plants are owned by Nitrogénmúvek Co. and found in Pét and Szolnok. Peremartoni Fertilizers Producter Ltd. is located in Peremarton. The market leader is Nitrogénmúvek Co.. The total capacity of the Hungarian firms is some 1900000 tons and $90 \%$ of this is produced by the market leader.

\section{Fertilizer trade}

Hungary has a supply market of artificial fertilizers. $80 \%$ of the fertilizer sales in Hungary are done by 12 companies. Half of the volume produced by the companies are sold to their 
domestic markets but they also produce for export to countries within the logistically economic about $600 \mathrm{~km}$ range. As a result, side by side with the domestically produced fertilizers import fertilizers are also present on the Hungarian Market.

According to Vágó et al. (2016) 50\% of the fertilizers sold in Hungary comes from domestic producers and $50 \%$ is imported. The total volume of imported fertilizers reaches farmers via traders and the overwhelming majority of domestic fertilizers also gets to farmers via dealers. The volume that gets to farmers directly from the producer is about $10 \%$.

The volume of the domestic fertilizer production between 2005 and 2015 is illustrated by Figure 2 .

Figure 2: The volume of fertilizers in effective matter sold in Hungary between 2000 and 2015

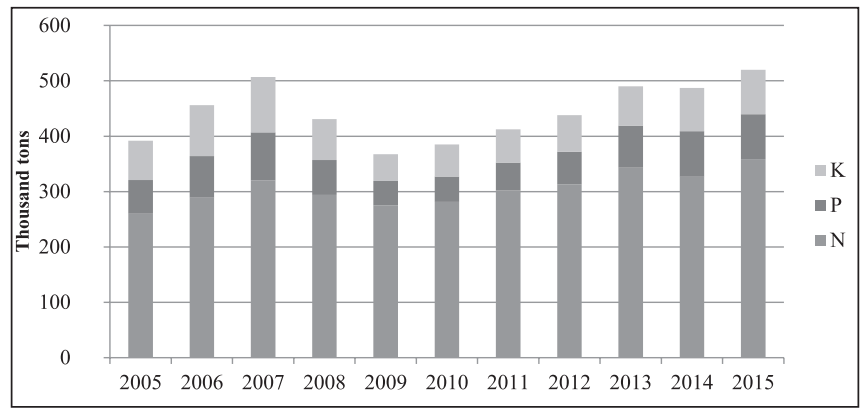

Source: HCSO, 2016 declared explosive) the volume of the earlier dominating ammonium nitrate decreased considerably and farmers use Calcium Ammonium Nitrate (CAN) to replace it.

The value of the fertilizers sold is illustrated by (Table 1)

As it is seen in the Table 1., simple fertilizers accounted for $60-70 \%$ of the ones sold over the period analyzed and within this nitrogen fertilizers had a share of $90-95 \%$.

Even in this case, what strikes the eyes is the volume increased due to the price explosion of 2008, which due to a decrease of up to $20 \%$, exceeded the volume of 2006 by about $70 \%$. Although this decreased somewhat in 2009, later, within six years doubled as a result of continuous increases and had risen to the level of 220\%, i.e., HUF 136.5 billion by 2015 .

Trends in fertilizer prices and the most important factors which influencing them

The price indices for fertilizers are shown in Table 2

Table 2 shows the changes in domestic fertilizer prices compared to those in 2005. All in all it can be claimed that the changes in fertilizer prices can be divided into two periods. Until 2012 there had been a very significant and dynamic change as a result of which the prices for N, P and K fertilizers went up by $80-120 \%$, nearly $160 \%$ and about $120 \%$, respectively. This was followed by a recovery of the market and until 2017 decreases of about 20-30\% can be observed compared to 2012 prices but the rate of these changes lag behind the prices in other European countries.

Considered in natural mass 1.489 million tons of fertilizers were sold directly to farmers, of which 1.142 million tons were single component fertilizers and 347 thousand tons were complex ones. The ratio of single component and complex fertilizers was 75:25 in 2015, i.e., there are no significant changes (KSH, 2016).

As regards the utilization of nitrogen fertilizers it is worth noting that wing to its safety hazard (it was

\begin{tabular}{|l|l|l|l|l|l|l|l|l|l|l|l|l|}
\hline & 2005 & 2006 & 2007 & 2008 & 2009 & 2010 & 2011 & 2012 & 2013 & 2014 & 2015 & 2016 \\
\hline N fertilizers & 100,0 & 117,3 & 126,7 & 185,4 & 164,6 & 154,1 & 194,9 & 213,7 & 206,5 & 204,5 & 207,2 & 179,7 \\
\hline P fertilizers & 100,0 & 99,0 & 118,5 & 250,2 & 231,5 & 193,1 & 231,5 & 251,2 & 254,8 & 230,5 & 227,4 & 229,7 \\
\hline K fertilizers & 100,0 & 111,3 & 111,9 & 248,8 & 279,0 & 198,4 & 231,5 & 258,5 & 250,0 & 216,9 & 226,0 & 210,5 \\
\hline $\begin{array}{l}\text { NPK fertil- } \\
\text { izers }\end{array}$ & 100,0 & 108,2 & 119,9 & 228,8 & 207,5 & 171,5 & 206,9 & 243,1 & 227,8 & 204,8 & 215,3 & 202,1 \\
\hline $\begin{array}{l}\text { Fertilizers } \\
\text { total }\end{array}$ & 100,0 & 114,4 & 124,7 & 201,5 & 180,5 & 161,3 & 200,6 & 223,9 & 214,7 & 206,3 & 211,6 & 187,9 \\
\hline
\end{tabular}

Table 1: The development of fertilizer sales in value over 2006-2015

HUF million

\begin{tabular}{|l|l|l|l|l|l|l|l|l|l|l|}
\hline Item name & 2006 & 2007 & 2008 & 2009 & 2010 & 2011 & 2012 & 2013 & 2014 & 2015 \\
\hline $\begin{array}{l}\text { Simple fertilizers } \\
\text { total }\end{array}$ & 40374 & 47655 & 64516 & 59880 & 51539 & 70446 & 77753 & 85919 & 78836 & 89208 \\
\hline \multirow{2}{*}{$\begin{array}{c}\text { of which: Nitrogen } \\
\begin{array}{c}\text { Phosphorus } \\
\text { Potassium }\end{array}\end{array}$} & 36360 & 43781 & 59030 & 56566 & 48326 & 66948 & 73534 & 81279 & 74570 & 84651 \\
\cline { 2 - 12 } & 3299 & 3441 & 5167 & 3190 & 2958 & 3120 & 3871 & 4351 & 4060 & 4243 \\
\hline $\begin{array}{l}\text { Complex fertilizers } \\
\text { total }\end{array}$ & 22067 & 28859 & 40966 & 22154 & 22504 & 34665 & 44302 & 43233 & 42550 & 45465 \\
\hline NPK fertilizers total & 62440 & 76514 & 105482 & 82034 & 74043 & 105111 & 122055 & 129152 & 121386 & 134673 \\
\hline $\begin{array}{l}\text { Other, non-NPK } \\
\text { fertilizers }\end{array}$ & n.a & n.a & 1643 & 1397 & 1487 & 802 & 1085 & 1171 & 1113 & 1793 \\
\hline Fertilizer sales total & 62440 & 76514 & 107125 & 83431 & 75530 & 105912 & 123140 & 130322 & 122499 & 136466 \\
\hline Change (\%) & 100,00 & 122,54 & 171,56 & 133,62 & 120,96 & 169,62 & 197,21 & 208,72 & 196,19 & 218,56 \\
\hline
\end{tabular}

Source: Research Institute of Agricultural Economics, 2017
Source: HCSO, 2017

Later an analysis of the trends in fertilizer prices between 2006 and 2015 followed (Figure 3). In each case the prices were proofcorrected to effective matter contents of $100 \%$. The average prices for the most popular and wide-spread fertilizers, such as ammonium-nitrate $(34 \%)$, urea (46.3\%) and CAN (27\%) were used. In the case of phosphorus and potassium I took the prices of super-phosphate (20\%) and potassium chloride (60\%) as bases. 
Figure 9: NPK fertilizer prices corrected to effective matter(2006-2015)

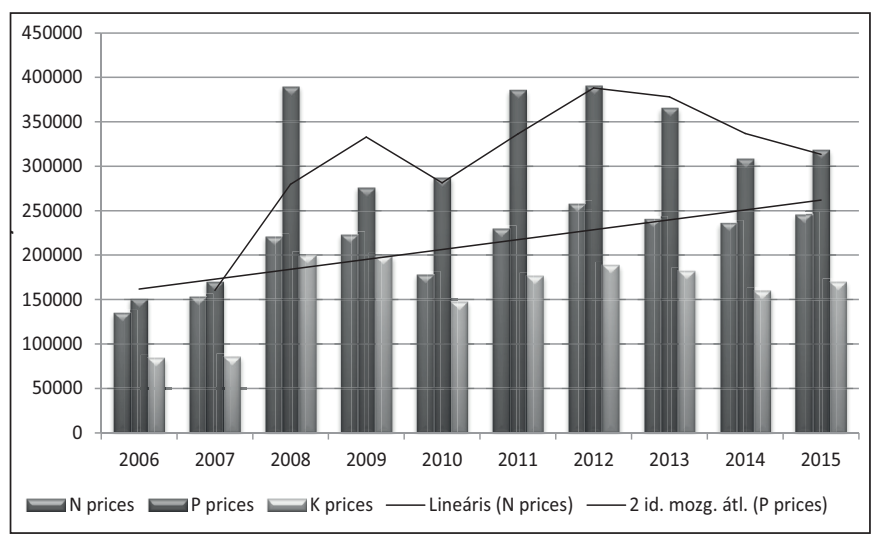

Source: Own calculations and compilation based on data, 2016

It can be well seen that fertilizer prices increased considerably in 2008 due to primarily the price explosion of fuels, which was followed by a decrease. After 2012, however, prices started decreasing again. With application of SPSS trend analyses were conducted. It is to be noted that a ten-year period cannot be regarded as a short one in the case of fertilizer application but as regards item numbers it is still very low, anyway. Basic trend, however, can be inferred from them. It can be concluded that there is an increasing trend function that matches nitrogen prices, but phosphorus prices are characterized by a seasonal character indicated by a two-digit unstable average and as regards potassium there are not any matches over this time span. Over the time period indicated prices of $\mathrm{N}, \mathrm{P}$ and $\mathrm{K}$ fertilizers increased by $82 \%$, $136 \%$ and about $26 \%$, respectively. Owing to the above, my hypothesis No. 1, which says that fertilizer prices in Hungary show continuous increases are discarded in the case of N, P and $\mathrm{K}$ fertilizers as well.

The individual factors potentially affecting prices were also analyzed, the results of which are contained in Table 3.

\section{Table 3: Correlations between fertilizers and some potential effective factors}

\begin{tabular}{|l|l|}
\hline Factors analyzed & Pearson correlation value \\
\hline $\begin{array}{l}\text { Fertilizer utilization in the given } \\
\text { year }\end{array}$ & 0,259 \\
\hline Corn prices in the previous year & 0,822 \\
\hline Wheat prices in the previous year & 0,919 \\
\hline $\begin{array}{l}\text { Precipitations over the given year } \\
\text { Mean temperature over the grow- } \\
\text { ing period in the given year }\end{array}$ & 0,396 \\
\hline $\begin{array}{l}\text { Prices for natural gas (with the } \\
\text { price of N) }\end{array}$ & $-0,649$ \\
\hline $\begin{array}{l}\text { Prices for crude oil (with the } \\
\text { price of } \mathrm{N} \text { ) }\end{array}$ & 0,464 \\
\hline
\end{tabular}

Source own private calculation
The date in the table lead to the following conclusions:

- My presupposition according to which annual prices for corn and wheat positively influence the fertilizer utilization over the given year is not proven, there is no correlation between the two factors. As a result I discard my hypothesis No. 2.

- There are not any correlations between the annual prices in the given year and fertilizer application either.

- On the other hand there is a close correlation revealed between fertilizer prices and corn and wheat prices of the preceding years, which presupposes that fertilizer traders observe economic results and as a result of higher crop prices increase fertilizer prices, too.

- There is a weak negative correlation between $\mathrm{N}$ fertilizer and crude oil prices and there is no correlation between domestic $\mathrm{N}$ fertilizer prices and world market crude oil prices. The former is an important factor because natural gas is one of the determining base materials of $\mathrm{N}$ fertilizers and fertilizer production involves high energy costs but as we can see it is not this fact that determines domestic fertilizer prices. The explanation may be that in Hungary the price calculation by the crucial actors on the fertilizer market is not cost-based but is aimed at increasing the demand on the one hand and increasing the market share on the other. For this reason I accept my hypothesis No 4.

\section{Fertilizer utilization}

In the EU the highest doses of $400 \mathrm{~kg}$ fertilizer per hectare on the average are applied in Luxemburg, which is followed by Ireland at almost the same level, then the Netherlands, Croatia and Belgium at $300 \mathrm{~kb} / \mathrm{ha}$ each. As regards Belgium's high fertilizer application the country's much higher than average (30 kg/ha) potassium application is also worth mentioning (World Bank, 2012). In Hungary similar doses (285 kg/ha) were applied between 1980 and 85 but this intense application entailed several negative consequences. As MARESELEK (2006) also highlights, industrialized farming started harmful, environmentpolluting trends. Environmental damage was mostly the result of the excessive use of fertilizers and plant protecting agents.

Our current domestic fertilizer utilization is ultimately determined by the application of $\mathrm{N}$ fertilizers. Phosphorus application is also of considerable significance but potassium application does not reflect the volumes of fertilizers applied in individual years. This leads to the conclusion that most of the farmers still focus on the application of nitrogen and phosphorus is also applied but potassium application is either neglected or not enough attention is paid to it.

I conducted a correlation analysis of the variables that may have effects on fertilizer application, such as fertilizer prices in the given year, fertilizer prices in the previous year, weather conditions (precipitation, temperature) in the given year as well as the results of the management in the previous year, which were then compared to the cereal (wheat and corn) prices in the previous year and also tried to find correlations between fertilizer application and wheat and corn yields. The analysis was conducted at $95 \%$ reliability.

The correlations between fertilizer application and certain active components are contained in Table 4. 
Table 4: Correlations between fertilizer application and some possible active components

\begin{tabular}{|c|c|}
\hline Factors analyzed & Pearson correlation value \\
\hline Nitrogen prices in the given year & 0,259 \\
\hline Phosphorus prices in the given year & 0,049 \\
\hline Potassium prices in the given year & $-0,173$ \\
\hline Nitrogen prices in the previous year & 0,284 \\
\hline Phosphorus prices in the previous year & 0,077 \\
\hline Potassium prices in the previous year & $-0,090$ \\
\hline Corn prices in the previous year & 0,478 \\
\hline Wheat prices in the previous year & 0,429 \\
\hline Annual precipitation in the given year & $-0,366$ \\
\hline $\begin{array}{l}\text { Mean temperature during the growing } \\
\text { season in the given year }\end{array}$ & 0,475 \\
\hline Wheat yield and $\mathrm{N}$ fertilizer application & 0,470 \\
\hline Wheat yield and P fertilizer application & 0,433 \\
\hline Wheat yield and $\mathrm{K}$ fertilizer application & 0,166 \\
\hline Corn yield and $\mathrm{N}$ fertilizer application & $-0,259$ \\
\hline Corn yield and $\mathrm{P}$ fertilizer application & $-0,155$ \\
\hline Corn yield and $\mathrm{K}$ fertilizer application & $-0,228$ \\
\hline $\begin{array}{l}\text { Average wheat yield and } \mathrm{N} \text { fertilizer } \\
\text { application }\end{array}$ & 0,467 \\
\hline $\begin{array}{l}\text { Average wheat yield and } \mathrm{P} \text { fertilizer } \\
\text { application }\end{array}$ & 0,261 \\
\hline $\begin{array}{l}\text { Average wheat yield and } \mathrm{K} \text { fertilizer } \\
\text { application }\end{array}$ & 0,188 \\
\hline $\begin{array}{l}\text { Average corn yield and } \mathrm{N} \text { fertilizer } \\
\text { application }\end{array}$ & $-0,297$ \\
\hline $\begin{array}{l}\text { Average corn yield and } \mathrm{P} \text { fertilizer ap- } \\
\text { plication }\end{array}$ & $-0,127$ \\
\hline $\begin{array}{l}\text { Average corn yield and } \mathrm{K} \text { fertilizer } \\
\text { application }\end{array}$ & $-0,042$ \\
\hline
\end{tabular}

Source: own private calculation

\section{The major findings of the study}

- No correlations can be shown between fertilizer application and fertilizer prices in the given year but although low, - however, stronger than with the given year- correlations are found between fertilizer application and fertilizer prices in the preceding year. This suggests that farmers mostly buy the fertilizer volumes they wish to apply not in the given but in the preceding year and store them.

- There is a negative correlation between fertilizer utilization and the price of potassium, which may lead to the conclusion that potassium is not necessarily applied by farmers even when its price is more favorable.

- My stipulation, according to which corn and wheat prices in the given year positively influence fertilizer application in the given year, was not proven and there is no correlation between the two factors.

- There is a weak correlation between fertilizer application and wheat yields in the given year but the former does not correlate with corn yields and the same can be said for average yields, too.

- There is, however, a close correlation revealed between fertilizer prices and corn and wheat prices in the preceding year, which suggests that fertilizer traders keep tabs on economic results and also increase fertilizer prices under the influence of higher prices. This conclusion is linked to my 3rd hypothesis but in lieu of certain data cannot be verified.

- The weather (precipitation and temperature) over the given year does not influence fertilizer application and thus I infer that weather related anomalies e.g. too much or too little precipitation in the given year are not made up for by farmers by applying higher doses of fertilizers.

\section{Trends on the domestic fertilizer market revealed by partial efficiency indicators}

To conclude the analysis I produced partial efficiency indicators for 2016, with the help of which conclusions may be drawn of further characteristics of the domestic fertilize market. The most important indicators are contained in Table 4.

Table 5: efficiency indicators of the fertilizer market

\begin{tabular}{|l|l|l|}
\hline $\begin{array}{l}\text { Domestic fertilizer market's indica- } \\
\text { tors }\end{array}$ & Value & Unit \\
\hline $\begin{array}{l}\text { Fertilizer dose per 1 ha (kg/ha) } \\
\text { agricultural land }\end{array}$ & 97 & $\mathrm{~kg} / \mathrm{ha}$ \\
\hline $\begin{array}{l}\text { Fertilizer dose per 1 ha (kg/ha) } \\
\text { arable land }\end{array}$ & 120 & $\mathrm{~kg} / \mathrm{ha}$ \\
\hline $\begin{array}{l}\text { Corn price - fertilizer price ratio } \\
(\%)\end{array}$ & 561 & $\%$ \\
\hline $\begin{array}{l}\text { Wheat price - fertilizer price ratio } \\
(\%)\end{array}$ & 577 & $\%$ \\
\hline $\begin{array}{l}\text { Rapeseed price - fertilizer price } \\
\text { ratio (\%) }\end{array}$ & 232 & $\%$ \\
\hline $\begin{array}{l}\text { Fertilizer mass } 1 \text { ton corn (t) can } \\
\text { buy }\end{array}$ & 0,18 & $\mathrm{t}$ \\
\hline $\begin{array}{l}\text { Fertilizer mass 1 ton wheat can } \\
\text { buy(t) }\end{array}$ & 0,17 & $\mathrm{t}$ \\
\hline Fertilizer mass 1 ton rapeseed (t) & 0,43 & $\mathrm{t}$ \\
\hline
\end{tabular}

Source: own private calculation 
As Table 5 reveals fertilizer application per 1 hectare in Hungary is below $100 \mathrm{~kg} / \mathrm{ha}$, which volume is below that in most EU member states and what is more shows a lower than global average $(120 \mathrm{~kg} / \mathrm{ha})$ value. When the above figure is calculated for arable land only, the value rises to $120 \mathrm{~kg} / \mathrm{ha}$.

As regards the correlations between buying up prices of the most important domestic crops and fertilizer prices, we can see that fertilizers account for $561 \%, 577 \%$ and $232 \%$ of corn, wheat and rapeseed prices, respectively. This in turn means that in 2016 the price of 1 ton of corn, wheat and rapeseed could buy $0.18,0.17$ and $0.43 \mathrm{t}$ fertilizers, respectively.

\section{REFERENCES}

Fertilizer Europe (2017): Annual Overview 2016

Hungarian Central Statistical Office (KSH, HCSO), (2016): Értékesített mútrágya mennyisége hatóanyagban (The volume in effective matter of fertilizers sold) (2000-) https://www.ksh.hu/ docs/hun/xstadat/xstadat_eves/i_omf002.html

Hungarian Central Statistical Office (KSH, HCSO), (2017): Price indices for artificial fertilizers on the basis of 2005 $(=100 \%)$.

Marselek, S. (2006): Környezeti állapot, mezőgazdaság, fenntartható fejlődés. (Environmental condition, agriculture, sustainable development.) Gazdálkodás, 50. évf. (Vol. 50), 15. különkiadás,Special ed. 15) pp.12-27.

Research Institute of Agricultural Economics, (2017): Department of Agricultural Statistics's database www.aki.gov. hu

Varga E. (2012): Helyzetkép és várakozások a mútrágyapiacon (The state of affars and expectation on the fertilizer market) In: AgrárUnió 13/3 pp. 14-15. ISSN 1589-6846

Varga É. - Vágó Sz. - Boldog V. - Kruppa B. (2012): A mútrágya és a növényvédô szerek felhasználásának üzemszintű vizsgálata néhány fontosabb növénytermesztési ágazatban (Across the farm analysis of fertilizers and plant protecting agents in some more important crop production sectors) In: Gazdálkodás $56 / 56 / 3$ pp. $230-242$. p ISSN 0046-5518

Varga É. (2016): Mûtrágya-értékesítés mezőgazdasági termelőknek (Fertilizer sales to agricultural producers) 2016. I-III. negyedév (quarters 3 and 4) in: Statisztikai jelentések XVII. évfolyam 4. szám 2016, Agrárgazdasági Kutató Intézet, ISSN 14182130

Vágó Sz. - Varga É. - Boldog V. (2016): A magyarországi mútrágyapiac múködése és főbb jellemzői, (The operation and the most important characteristics of the fertilizer market in Hungary) Gazdálkodás 2016/1 p51-65 ISSN 0046-5518

World Bank (2012): Fertilizer consumption (kilograms per hectare of arable land), http://data.worldbank.org/ indicator/AG.CON.FERT.ZS/countries?order=wbapi_data_ value_2007\%20wbapi_data_value\&sort $=$ desc\&display $=$ graph 
